\title{
Glaciological activities in the Johan Dahl Land area, South Greenland, as a basis for mapping hydropower potential
}

\section{Poul Clement}

Along the margin of the Inland Ice several basins have been proposed as possible areas for hydropower production (ACG/VBB, 1975). One of the most promising localities was (and still is) the Nordbosø basin in Johan Dahl Land, South Greenland. With a mean annual runoff from Nordbos $\varnothing$ of 140 million $\mathrm{m}^{3}$ and a powerhead of $640 \mathrm{~m}$, an annual production of approximately $200 \mathrm{GWh}$ would result (ACG/VBB, 1980).

In the Nordbos $\varnothing$ basin Nordbogletscher is the main water source, as ablation from the glacier contributes with $60-70 \%$ of the annual runoff. An understanding of the glaciological conditions including mass balance, glacier dynamics, drainage of ice-dammed lakes, and climate-ablation relationships, is essential for the whole project.

In a joint project with the Greenland Fisheries Investigations (environmental studies) and the Greenland Technical Organization (engineering and hydrological studies), GGU is responsible for the glaciological work, and in the 1983 field season the glaciological investigations were continued for the sixth year. The project is supported by the Danish Ministry of Energy.

\section{Glaciological setting of Johan Dahl Land}

The Johan Dahl Land area is bounded by the Inland Ice on three sides. To the west and to the east the big outlet glaciers Eqalorutsit kangigdlit sermiat and Qôrqup sermia flow down to sea level (fig. 49), while to the north the outlet glaciers (Nordbogletscher, Nordgletscher and Østgletscher) all have their terminus at elevations of $600-700 \mathrm{~m}$ above sea level.

Nordbogletscher has been advancing for most of this century. The glacier is characterized by missing trimline zones and lack of older moraines along the margins. From depth soundings in Nordbos $\emptyset$ no former end moraines have been detected and the front position seems to be the outermost in historic time. The earliest information about the glacier is obtained from an aerial photograph taken by the Danish Geodetic Institute in 1942. Since that time the glacier snout has advanced $665 \mathrm{~m}$ and diminished the area of the Nordbos $\varnothing$ reservoir by $0.4 \mathrm{~km}^{2}$. The adjacent glaciers Eqalorutsit kangigdlit sermiat and Nordgletscher have also advanced considerably during recent years. Nordgletscher has thus advanced 650 $m$ since 1947. The advance of Eqalorutsit kangigdlît sermiat is more difficult to estimate because of the floating and calving ice front, but the margins of the glacier have expanded into vegetation zones.

It should be noted that it is a whole sector of the Inland Ice which is advancing. The main drainage of ice in the area is directed towards the valley containing Eqalorutsit kangigdlit sermiat; both Nordbogletscher and Nordgletscher can be regarded as a kind of overspill from that direction. The other main drainage system is through Qôrqup sermia; this sector, however, has been retreating during most of this century. The reason why one sector is advancing while the adjacent sector is retreating is unknown, but seems to be a matter of dynamics rather than of climate. The time of the beginning of the advance is uncertain, but 


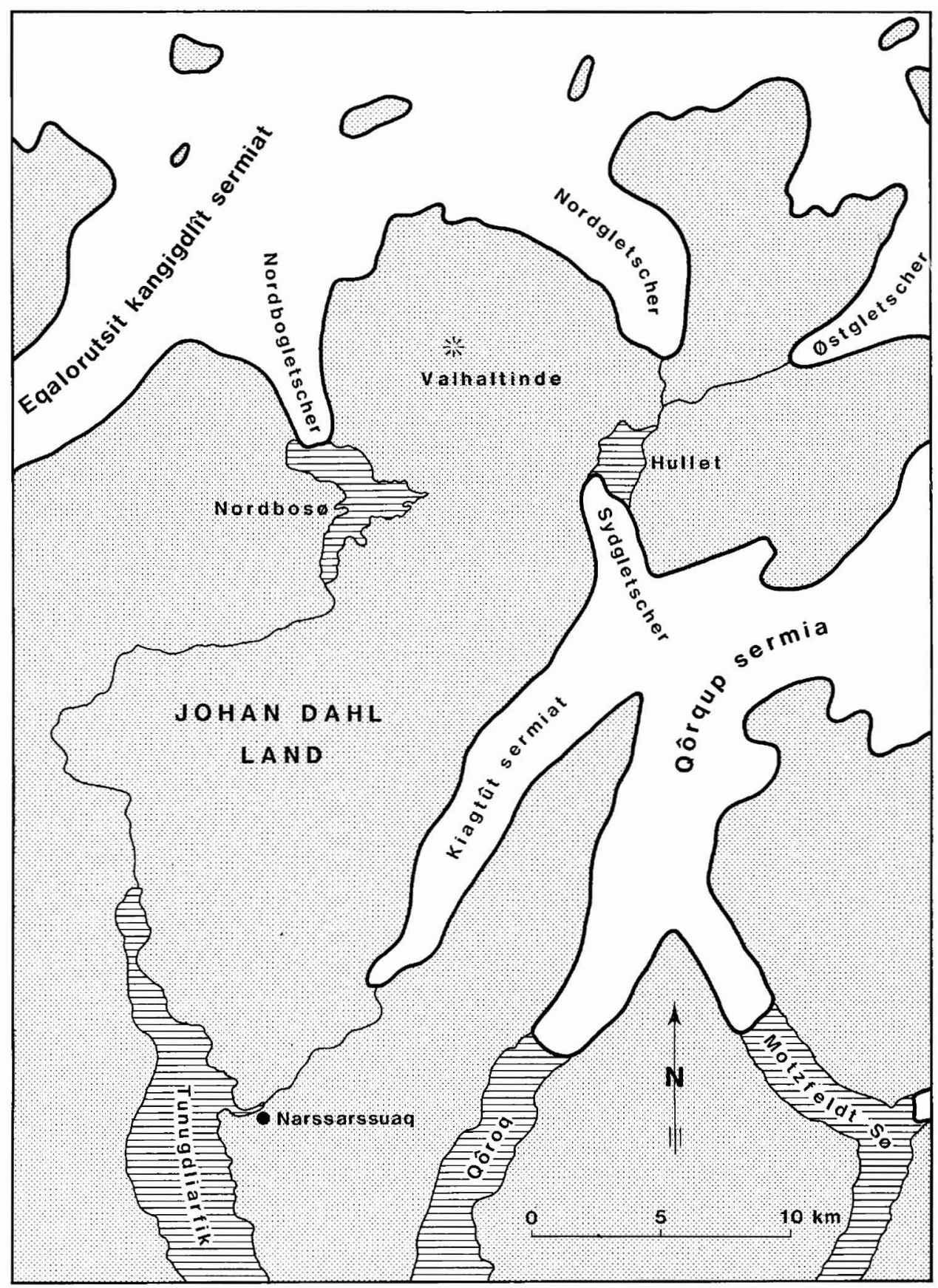

Fig. 49. Sketch map of the Johan Dahl Land area in South Greenland. 
Table 6. General information on glaciers studied in South Greenland, 1983, together with the collected mass balance data for the budget year 1982/83

\begin{tabular}{|c|c|c|c|}
\hline Glacier name & Narssaq Bre & Valhal tindegletscher & Nordbogletscher \\
\hline Glacier code no. & 1AG01001 & 1AG05008-9 & 1AG05001 \\
\hline Glacier position & $60^{\circ} 58^{\prime} \mathrm{N}, 48^{\circ} 58^{\prime} \mathrm{W}$ & $61^{\circ} 26^{\prime} \mathrm{N}, 45^{\circ} 21^{\prime} \mathrm{W}$ & $61^{\circ} 25^{\prime} \mathrm{N}, 45^{\circ} 23^{\prime} \mathrm{W}$ \\
\hline Glacier type & local glacier & local glacier & outlet glacier \\
\hline Glacier area, $\mathrm{km}^{2}$ & 1.4 & 1.9 & $?$ \\
\hline Elevation of front, $\mathrm{m}$ a.s.l. & 900 & 1080 & 660 \\
\hline mlevation of highest point, m a.s.l. & 1275 & 1630 & $2140(?)$ \\
\hline Distance from coast, $\mathrm{km}$ & 45 & 110 & $100-140$ \\
\hline Winter balance, $B_{w}, 10^{6} \mathrm{~m}^{3}$ & 1.66 & 1.04 & \\
\hline Mean specific winter balance, $b_{w}$, m & 1.16 & 0.55 & 0.63 \\
\hline Summer balance, $B_{\mathrm{s}}, 10^{6} \mathrm{~m}^{3}$ & -1.09 & -0.72 & \\
\hline Mean specific sumner balance, $b_{s}, m$ & -0.76 & -0.38 & $(-0.38)$ \\
\hline Net balance, $B_{n}, 10^{6} \mathrm{~m}^{3}$ & 0.57 & 0.32 & \\
\hline Mean specific net balance, $b_{n}$, m & 0.40 & 0.17 & $(0.25)$ \\
\hline Equilibrium line, m a.s.l. & 1100 & 1340 & 1300 \\
\hline
\end{tabular}

there is historic evidence that advancing ice buried Norse ruins at the beginning of 1800 (Weidick, 1982).

Besides the Inland Ice there are several local glaciers in Johan Dahl Land, situated at elevations from 1100 to $1650 \mathrm{~m}$ above sea level. None of the local glaciers have been shown on the Danish Geodetic Institute map sheets, but they have been detected on aerial photographs. The largest of the local glaciers occupies the northern slopes of Valhaltinde (fig. 49). This glacier, Valhaltindegletscher, has been mapped by GGU on the scale of 1:20 000 and is useful as a 'reference' for the logistically more difficult work on Nordbogletscher in connection with the mass balance studies. All the local glaciers seem to be retreating.

\section{Mass balance measurements in the budget year 1982/83}

As in earlier years the mass balance measurements were carried out on three glaciers lying on a profile from the coast to the Inland Ice at approximately $61^{\circ} \mathrm{N}$. The technique used in the field is in accordance with international standards, described by Østrem \& Stanley (1969) and UNESCO (1970). The net balance curves obtained from the three glaciers are shown in fig. 50, while the data and general information are given in Table 6 .

Narssaq Bra. The glacier is a small cirque glacier north of Narssaq with an area of 1.4 $\mathrm{km}^{2}$. Because of considerable shrinkage since 1900 the glacier is now separated into two parts by a bed-rock exposure. The glacier has thus two accumulation basins, one basin (no. 


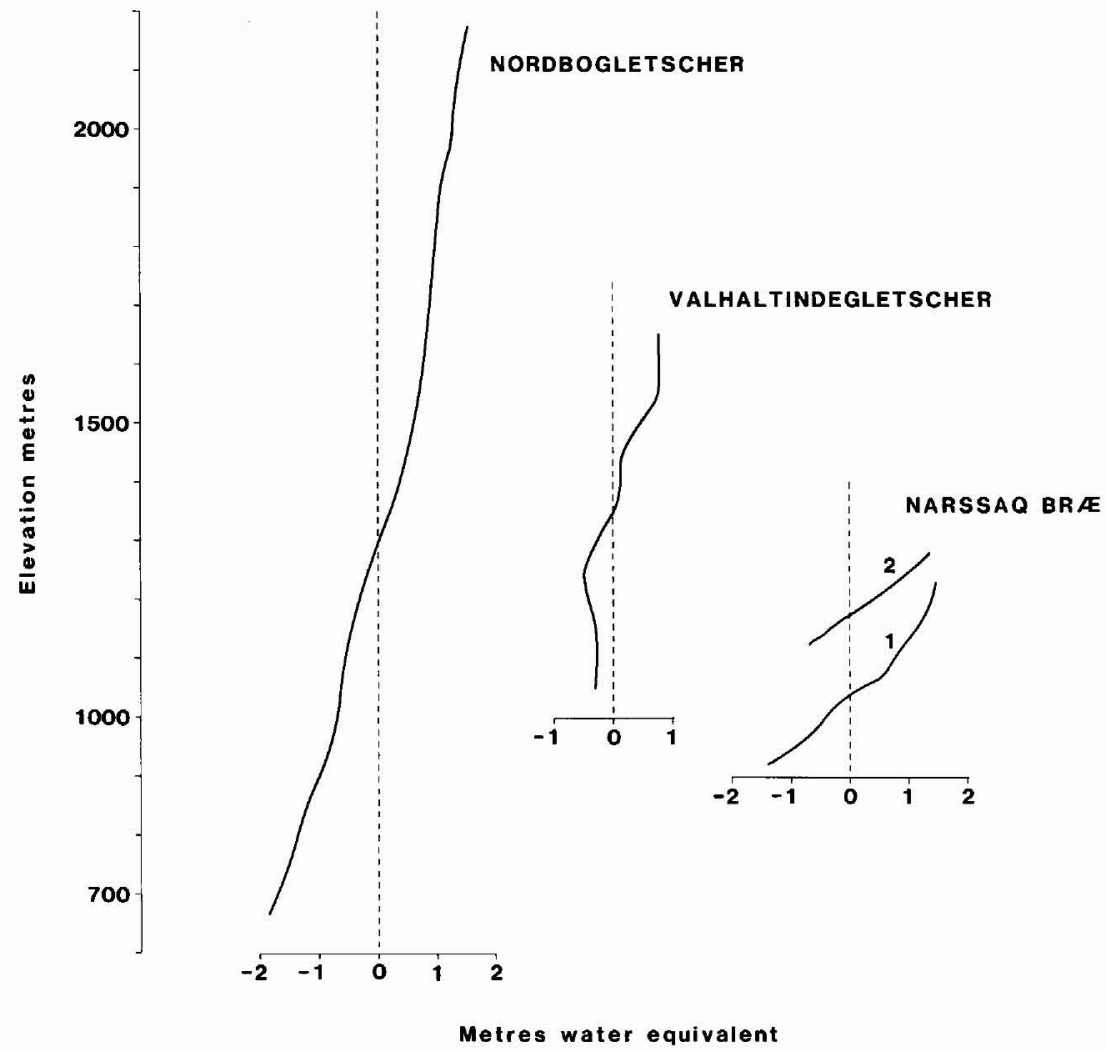

Fig. 50. Net balance curves for the three glaciers studied in South Greenland during the budget year $1982 / 83$.

1, fig. 50) faces east, the other north, giving rise to differences in exposure and accumulation/ablation conditions. The winter balance was measured on the 21st of May. The glacier was entirely snow covered, from $1 \mathrm{~m}$ of snow near the snout to more than $3 \mathrm{~m}$ of snow in the upper part of the accumulation areas. The total winter balance calculated was 1.7 million $\mathrm{m}^{3}$, corresponding to a specific mean value of $1.16 \mathrm{~m}$ of water equivalent. The summer balance was determined at the stakes at the end of August and was -1.1 million $\mathrm{m}^{3}$, or as a mean for the whole glacier area $-0.76 \mathrm{~m}$ of water equivalent. The glacier this year thus has a positive balance (Table 6). The equilibrium line was at different elevations in the two basins, but a mean value of $1100 \mathrm{~m}$ above sea level can be quoted.

Valhaltindegletscher. The glacier is situated in the northern part of Johan Dahl Land between Nordbogletscher and Nordgletscher (fig. 49). It is of a mixed type between a cirque glacier and small ice cap; the total area is $1.9 \mathrm{~km}^{2}$. The winter balance was measured on the 26th of May to give a total of 1.0 million $\mathrm{m}^{3}$, i.e. a specific value of $0.55 \mathrm{~m}$ water equivalent. The summer balance was measured at the end of August and calculated as -0.7 million $\mathrm{m}^{3}$, corresponding to a specific value of $-0.38 \mathrm{~m}$ of water equivalent. The mass balance this year was positive and the equilibrium line at $1340 \mathrm{~m}$ above sea level. 


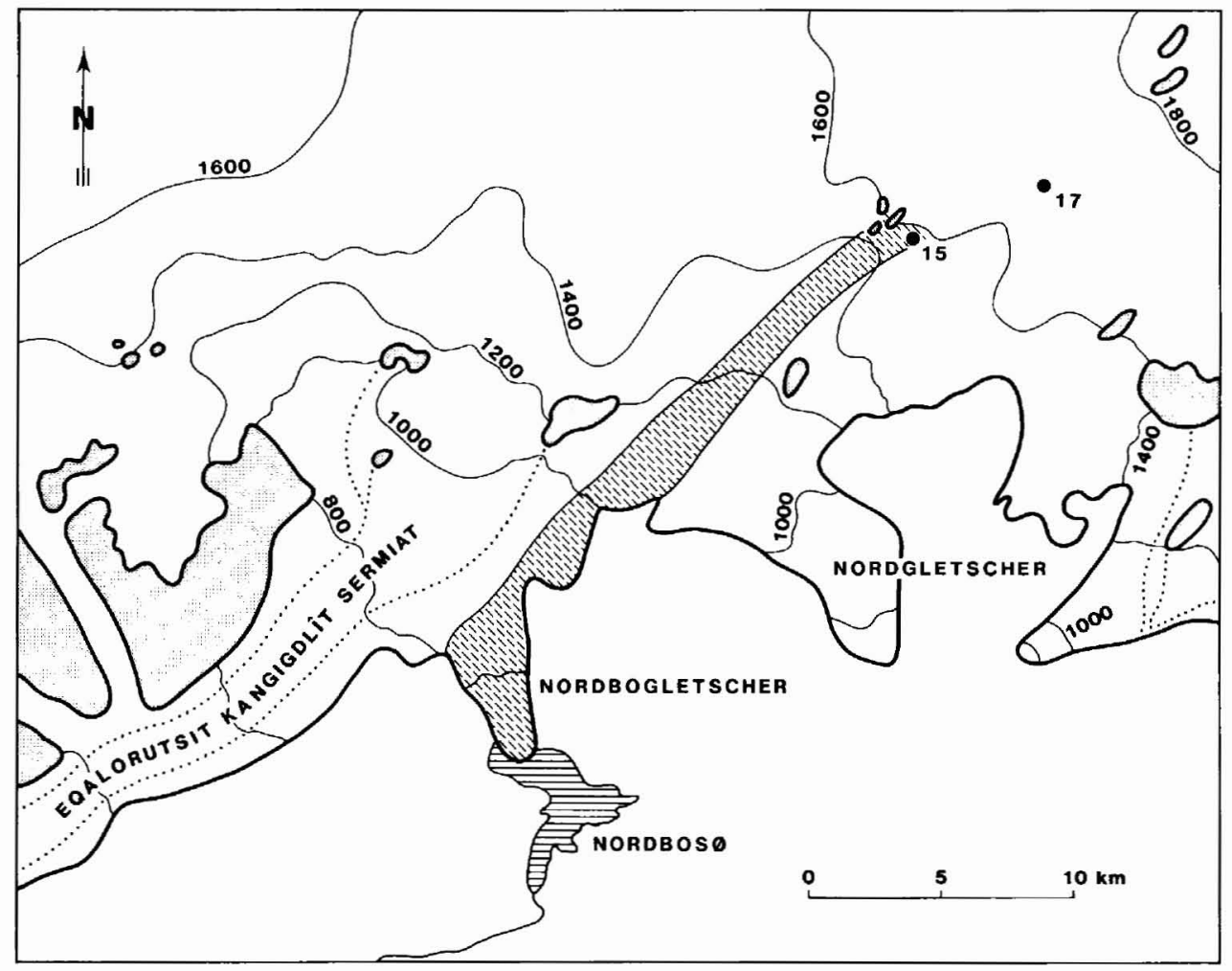

Fig. 51. Map showing the ablation area of Nordbogletscher together with locations for temperature measurements.

Nordbogletscher. While Narssaq Bræ and Valhaltindegletscher are well defined small glaciers with known areas and suitable for mass balance studies the situation is quite different on Nordbogletscher. Nordbogletscher is part of the Inland Ice and the boundaries with the neighbouring glaciers are very uncertain, especially at higher elevations. Furthermore, a topographic area based on map sheets does not have to be identical with the hydrological one, i.e. the area from where meltwater would contribute to the runoff from Nordbosø. In earlier papers and reports (Clement, 1982, 1983) GGU has worked in a topographic area of $208 \mathrm{~km}^{2}$; new results using satellite images from which subglacial features can be traced (Thomsen, 1983) show that the original area was too optimistic and must be reduced. At present the extent of the accumulation area is unknown, while the ablation area is approximately $57 \mathrm{~km}^{2}$ (from $660 \mathrm{~m}$ above sea level to $1500 \mathrm{~m}$ above sea level, fig. 51).

Because of the delineation problem in the accumulation area, it is difficult to calculate totals in mass balance terms, but the specific value at the stakes will give valuable information about accumulation and ablation conditions in the different elevation bands (fig. 50). The mass balance totals from former years (Clement, 1982, 1983) have to be recalculated when the area problem has been solved. 
The winter balance on Nordbogletscher was measured at the stakes in May. The results show a rather uniform distribution with elevation, and a mean specific value of $0.63 \mathrm{~m}$ of water equivalent was found. As a rough estimate the specific summer balance from Valhaltindegletscher can be transferred to Nordbogletcher. The specific mass balance (Table 6) is then positive. From the net balance curve the equilibrium line is found to be at $1300 \mathrm{~m}$ above sea level, about $250 \mathrm{~m}$ lower than observed for the last two years.

Comparing the three glaciers one finds that the elevation of the equilibrium line increases from the coast to the interior of the country, while the mass exchange decreases. The positive mass balance this year is mainly a result of the very cold summer in Greenland. It is the first year since measurements started in 1978 that the mass balance has been positive.

\section{Englacial temperature measurements}

For measuring englacial temperatures two sets of thermistor-strings were drilled down to a depth of $10 \mathrm{~m}$ in the accumulation area of Nordbogletscher (fig. 51). The thermistors were frozen into the drill holes, and resistance was read on a multimeter at the beginning and at the end of the summer season. A calibration curve of temperature against resistance was established. The temperature profiles obtained are shown in fig. 52, together with the cores taken in May.

At both places the winter accumulation 1982/83 was close to $2 \mathrm{~m}$ of snow. At stake 15 ( $1500 \mathrm{~m}$ above sea level) there was pure ice beneath the snowpack, while at stake $17(1740 \mathrm{~m}$ above sea level) there was firn interrupted by thick ice layers.

At stake 15 the minimum temperature in May was $-4.8^{\circ} \mathrm{C}$ at a depth of $4 \mathrm{~m}$. During the summer the snow layer had been raised to $0^{\circ} \mathrm{C}$; the ice was also warmer but temperatures remained below $0^{\circ} \mathrm{C}$. Meltwater from the surface either drained to lower elevations on top of the ice or refroze as superimposed ice upon the ice. The area belongs to the superimposed ice zone, as defined by Paterson (1981).

At stake 17 the minimum temperature in May was $-8.7^{\circ} \mathrm{C}$. At the end of the summer the top $6 \mathrm{~m}$ of snow and firn was $0^{\circ} \mathrm{C}$ while the temperature at $10 \mathrm{~m}$ depth was $-1.5^{\circ} \mathrm{C}$. The area belongs to the wet-snow zone. Surface melting occurred at stake 17 and the whole winter snow warmed to $0^{\circ} \mathrm{C}$ but there was no runoff from the area because of refreezing in the deeper layers. The same phenomenon was measured at an elevation of $2060 \mathrm{~m}$ (Braithwaite et al., 1982), where temperatures at a depth of $10 \mathrm{~m}$ in the firn were below $-3^{\circ} \mathrm{C}$.

The difference in warming the snow and ice at the two stakes should be noted. At stake 15 warming was mainly due to conduction through the ice, while at stake 17 warming was due to melting/refreezing, a much more effective process.

\section{Climate - ablation relationships}

In the ablation area of Nordbogletscher (fig. 51) a total number of 25 stakes have been drilled into the ice, covering different elevations from the snout to the equilibrium line. As the temperature measurements have shown, there is very limited, or no, runoff from the accumulation area. In calculating the total amount of ablation to Nordbosø one has only to take account of the ablation below $1500 \mathrm{~m}$ above sea level as a first approximation, i.e. from an area of $57 \mathrm{~km}^{2}$. From knowledge of the elevation/area distribution and the measured ablation at different elevations, the total amount of ablation can be calculated (Table 7). 


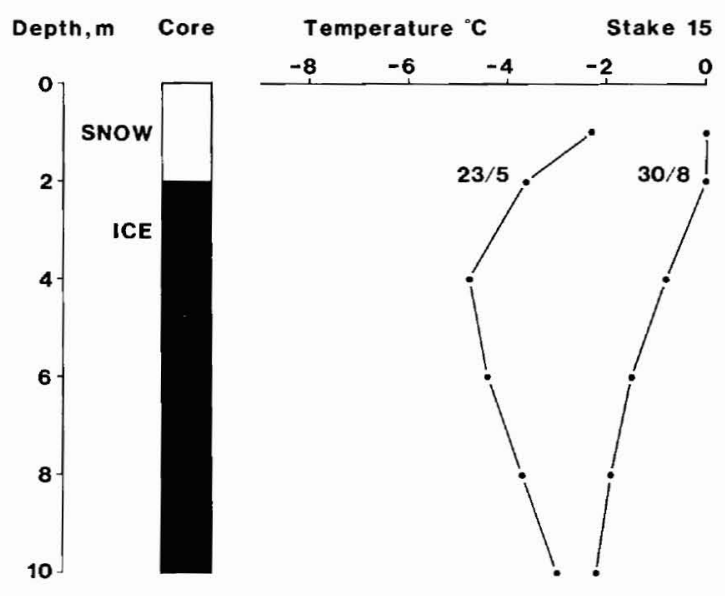

Fig. 52. Results from temperature measurements at stake $15(1500 \mathrm{~m}$ above sea level) and stake $17(1740 \mathrm{~m}$ above sea level) in the accumulation area of Nordbogletscher 1983. The cores show the situation in May. The positions of the stakes are shown in fig. 51.
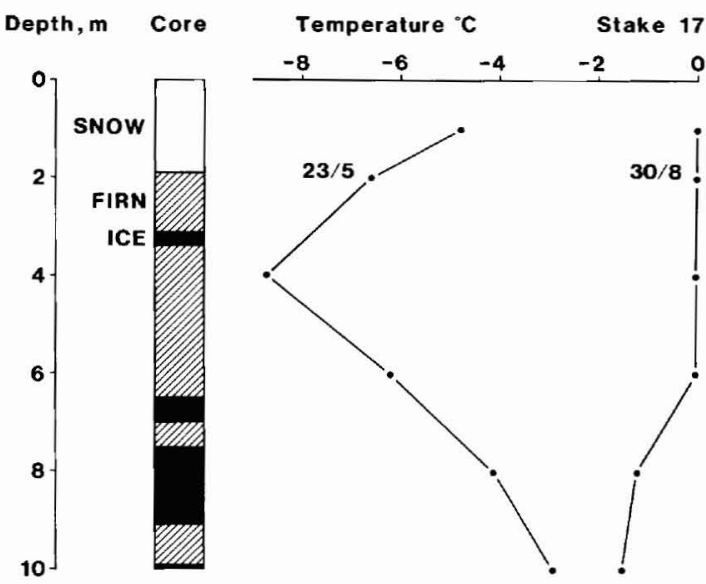

At the GGU base camp station near the margin of Nordbogletscher at an elevation of 850 $\mathrm{m}$ above sea level a full climatological programme comprising measurement of temperature, humidity, sunshine hours, radiation and precipitation was run during the summer months. In Table 7 the mean summer temperature (June to August) at base camp is given together with the mean summer temperature at the Meteorological Institute at Narssarssuaq ( $26 \mathrm{~m}$ above sea level). Between the two stations a lapse rate of $0.6^{\circ} \mathrm{C} / 100 \mathrm{~m}$ is found.

Comparing the temperatures at the base camp with the total ablation on Nordbogletscher an excellent correlation is found $\left(r^{2}=0.95\right)$. The similar correlation with temperatures at Narssarssuaq is $r^{2}=0.88$. Temperature is the main factor controlling ablation. A rise in mean summer temperature of just $2^{\circ} \mathrm{C}$ can increase the amount of ablation $100 \%$ (Table 7). It may be possible to use the results to construct models using temperatures at Narssarssuaq for predicting ablation on Nordbogletscher. 
Table 7. Total amounts of ablation from Nordbogletscher and mean summer temperatures (June to August) during the period 1979-1983

\begin{tabular}{lcccc}
\hline & \multicolumn{2}{c}{$\begin{array}{c}\text { Ablation on Nordbogletscher } \\
10^{6} \mathrm{~m}^{3}\end{array}$} & \multicolumn{2}{c}{ Mean temperature ${ }^{\circ} \mathrm{C}$} \\
\hline 1979 & 84.3 & 1480 & Base Camp & Narssarssuaq \\
1980 & 94.5 & 1660 & 3.7 & 9.3 \\
1981 & 109.9 & 1930 & 4.2 & 9.2 \\
1982 & 85.4 & 1500 & 4.7 & 9.7 \\
1983 & 57.8 & 1010 & 3.6 & 8.7 \\
\hline
\end{tabular}

\section{Other investigations}

Glacier velocity on Nordbogletscher was measured by theodolite to stakes from fixed points established on the ground. The yearly velocity on the central part of the tongue (850 $\mathrm{m}$ above sea level) was $90 \mathrm{~m} / \mathrm{a}$ increasing to $350 \mathrm{~m} / \mathrm{a}$ at elevations of $1050 \mathrm{~m}$ above sea level. The measured velocities are small in comparison with the high speed of Eqalorutsit kangigdlît sermiat, $1500 \mathrm{~m} / \mathrm{a}$ at an elevation of $600 \mathrm{~m}$ above sea level (Knudsen, 1983). Nordbogletscher is just an overspill from the main ice-drainage direction (fig. 51).

The ice-dammed lake Hullet (fig. 49) was kept under observation. Since the last outburst in October 1981 the lake has been refilling. This summer the critical level of $530 \mathrm{~m}$ above sea level was reached at the end of August, and drainage took place during September when the lake level fell to $420 \mathrm{~m}$ above sea level. During an outburst approximately 600 million $\mathrm{m}^{3}$ of water are discharged, and the river plain at Narssarssuaq is flooded.

\section{Discussion and outlook}

One of the main aims in Johan Dahl Land was to measure the mass balance of Nordbogletscher. However, big problems have arisen because the glacier is far from being well defined. The investigations have shown that a splitting up of the Inland Ice into individual sectors based upon topographic map sheets is artificial and of little use in glacier hydrological studies. A hydrological map based on information from satellite images and radio-echo soundings has to be made before totals in mass balances can be calculated.

On the other hand the investigations have shown that runoff from the accumulation area is very limited. Thus it can be ignored when calculating the amount of ablation.

The influence of Nordbogletscher on the proposed hydropower project is obvious, as most of the water originates from ablation. The mean specific runoff from the ablation area is $1500 \mathrm{~mm}$ (Table 7), while runoff from the glacier-free area only amounts to approximately $500 \mathrm{~mm}$. The ablation is dependent upon temperature, i.e. runoff from the glacier is dependent upon temperature, while the runoff from the glacier-free part is dependent on precipitation.

The investigations in Johan Dahl Land are unique, as it is the only place in Greenland 
where ablation and runoff from the Inland Ice have been measured simultaneously. It has thus been possible to compare the results and to find the discrepancies. As a consequence, the whole matter of determining areas on the Inland Ice has to be critically revised. The delineation problem on the Inland Ice is not restricted to Johan Dahl Land, but will occur at other places where the glaciers are not well defined. The results and experiences from Nordbogletscher may be useful at other basins proposed for hydropower.

\section{References}

ACG/VBB 1975: Lokalisering af vandkraftressourcer på Grønlands vestkyst. Arctic Consultant Group \& Vattenbygnadsbyrån, Lyngby \& Stockholm, 58 pp.

ACG/VBB 1980: Johan Dahl Land vandkraft. Projektskitse. Arctic Consultant Group og Vattenbygnadsbyrån, Lyngby \& Stockholm, 19 pp.

Braithwaite, R. J., Clement, P. \& Clausen, H. 1982: Inferences from a $19 \mathrm{~m}$ firn core, Nordbogletscher, South Greenland. Rapp Grønlands geol. Unders. 110, 96-98.

Clement, P. 1982: Glaciological investigations in connection with hydropower, South Greenland. Rapp. Grønlands geol. Unders. 110, 91-95.

Clement, P. 1983: Mass balance measurements on glaciers in South Greenland. Rapp. Grønlands geol. Unders. 115, 118-123.

Knudsen, N. T. 1983: Photogrammetric investigations at glaciers in West Greenland. Rapp. Grønlands geol. Unders. 115, 115-117.

Østrem, G. \& Stanley, A. 1969: Glacier mass balance measurements. A manual for field and office work. 125 pp. The Canadian Department of Energy, Mines and Resources and The Norwegian Water Resources and Electricity Board.

Paterson, W. S. B. 1981: The physics of glaciers. 380 pp. London: Pergamon.

Thomsen, H. H. 1983: Satellitdata - et redskab til studier af Indlandsisens randzone i forbindelse med vandkraftundersøgelser. Grønlands geol. Unders., Gletscher-hydrol. Meddr 83/8, 24 pp.

UNESCO 1970: Combined heat, ice and water balance at selected glacier basins. Tech. Pap. Hydrol. 5, $20 \mathrm{pp}$.

Weidick, A. 1982: Klima- og gletscherændringer i det sydlige Vestgrønland i de sidste 1000 år. Grønland 1982, 235-251. 